\title{
Immunomodulatory Effect of Lactoferrin on Mucosal Immunity of Uterus in Pregnant Rat
}

\author{
Nada Mohamed Ali Hashem*, Faheim El Bahay Wehaish and Youssef Yahia Elseady \\ Department of Physiology, Faculty of Veterinary Medicine, Mansoura University, Egypt \\ *Corresponding author: Nada Mohamed Ali Hashem, Department of Physiology, Faculty of Veterinary Medicine, \\ Mansoura University, Mansoura, 35516, Egypt
}

\section{ARTICLE INFO}

Received: July 16, 2021

Published: 幽 August 05, 2021

Citation: Nada Mohamed Ali Hashem, Faheim El Bahay Wehaish and Youssef Yahia Elseady. Immunomodulatory Effect of Lactoferrin on Mucosal Immunity of Uterus in Pregnant Rat. Biomed J Sci \& Tech Res 37(5)-2021. BJSTR. MS.ID.006061.

Keywords: Immunity; Lactoferrin; Cytokines; Immune Cells; Gene Expression; Uterus

\begin{abstract}
Immunity stabilization in early pregnancy is one of the most reasons for the establishment of gestation. Lactoferrin is an iron-binding glycoprotein which proved to has a positive effect on immunity including broad-spectrum antimicrobial activity, regulation of cell growth and differentiation, and intonation of inflammatory as well as humoral and cellular immune responses. So, this study aimed to examine some immune parameters, cells and cytokines during early Pregnancy. Twenty-four mature female and six male rats for mating were subjected to this investigation. They were grouped into two groups, the control and lactoferrin group treated daily with Lactoferrin with a dose of $50 \mu \mathrm{gm} / \mathrm{kg}$ body weight orally starting from one week before and persisted for one week after mating. Blood samples were collected from each female rat at $5 \mathrm{hrs}$, 1 day,3days, and 7 days after mating for hematological and biochemical assay Extracted RNA was subjected to real-time PCR to determine mRNA levels for immune- related genes interleukin1A(IL1A) and interleukin 10(IL10). Histopathological examination was done on the uterus. Results showed a significant increase in white blood cell count, mainly neutrophil, eosinophil, and basophil, mainly at $5 \mathrm{hrs}$ and 7-days of the lactoferrin group. Similarly, C- reactive protein and progesterone in the lactoferrin group at 3 and 7 days were significantly increased. Also, significant increases in the levels of interleukin $1 \mathrm{~A}$ at all experimental periods were noticed, while interleukin 10 was increased at 1 day and 3 days after mating in the Lactoferrin treated group. TNF increased significantly at $5 \mathrm{hrs}$, 1 days, and 7 days. In contrast, estrogen decreased significantly at $5 \mathrm{hrs}$ and 1 day while Total Antioxidant Capacity (TAC) decreased at $5 \mathrm{hrs}$ and 3 days and 7 days of Lactoferrin treated group. Moreover, histopathological examination revealed high leukocytic infiltration, especially neutrophil and eosinophil, at 5hrs hours after mating in the Lactoferrin treated group. This research demonstrated that using Lactoferrin during Pregnancy has a good impact on some immune cytokines and parameters that may improve immune status during early pregnancy.
\end{abstract}

Abbreviations: 5HRS: Five hours; AST: Assisted Reproductive Technology; BLF: Bovine Lactoferrin; CRP: c- Reactive Protein; CDNA: Complementary DNA; CT: Computed Tomography; DW: Distilled Water; IL1A: Interleukin 1a; IL1B: Interleukin 1b; IL4: Interleukin 4; IL10: Interleukin 10; LF: Lactoferrin; MRNA: Messenger Ribonucleic Acid; NRC: National Research Council; P4: Progesterone; PR-A: Progesterone Receptor a; PR-B: Progesterone Receptor b; PMNS: Polymorphonuclear Cells; PCR: Polymerase Chain Reaction Test; TH1: T elper1; TNF: Tumor Necrosis Factor; TAC: Total Antioxidant Capacity; RNA: Ribonucleic Acid; WBCS: White Blood Cells 


\section{Introduction}

Disturbances in early Pregnancy and endometrial receptivity are the major causes of subfertility and also impact placental improvement and fetal growth [1], which has implications for the phenotype of the offspring and capacity to withstand health challenges in later life [2]. Key regulators of the conception and implantation events are maternal tract cytokines and immune cells within the female reproductive tract, while the receptivity of the endometrium is dependent on immune cells present at the implantation site [3]. In mice and rats, implantation was between days 4 and 5 of Pregnancy, considering the first day of Pregnancy as the day on which a vaginal plug or spermatozoa are present in the vagina [4]. Lactoferrin (LF) was a very important part of the human body's natural defense system [5]. Lactoferrin is a cellsecreted mediator that links innate and adaptive immune function in mammals. It is a pleiotropic molecule that directly supports the influence of presenting cells for the development of T-helper cell polarization [6].

In vitro, Lactoferrin stimulates the growth of lymphocytes [7], natural killer activity [8], and the release of interleukin-8 (IL8) from neutrophils. Further, Lactoferrin stimulates the release of IL 1, IL 2, and tumor necrosis factor (TNF) from leukocytes or complement activation [9]. LF and its derivatives have pleiotropic functions, including broad-spectrum antimicrobial activity, regulation of cell growth and differentiation, and intonation of inflammatory as well as humoral and cellular immune responses [10]. During Pregnancy, the peripheral-specific immune response is shifted away from a type 1 cellular immune response towards a type 2 humoral immune response [11]. During rat pregnancy, both monocyte and granulocytes increased in number in circulation [12]. There is an absolute monocities during Pregnancy, especially in the first trimester, but decreases as gestation advances. Monocytes help in preventing fetal allograft rejection by infiltrating the decidual tissue from seven to twenty weeks of gestation, possibly through prostaglandin E2 mediated immunosuppression [13].

In fact, the uteroplacental tissue produces an array of antiinflammatory cytokines as interleukin 10 that are expressed in the uterus, oviducts, and ovaries of cycling mice and during Pregnancy in the uterine myometrium and cervix [14-20]. Thus, the balance between pro-inflammatory cytokines as tumor necrosis factor (TNF) and interleukin 1a and anti-inflammatory cytokines is essential to a successful pregnancy outcome [21]. IL1A is one of the major cytokines that participate in the local regulation of many reproductive affairs. IL1A also plays a role in regulating ovulation [22]. TNF- $\alpha$ has been shown to influence hormone synthesis, placental architecture, embryonic and follicle development, steroidogenesis, uterine cyclicity, placental differentiation, and parturition [23,24]. [25-30] hypothesized that Pregnancy is a stressful condition as it leads to increased levels of oxidants and therefore reduces Total Antioxidant Capacity (TAC). C- Reactive Protein (CRP) is a sensitive marker of systemic inflammation and is primarily synthesized in hepatocytes in response to infection and tissue injury. Production of CRP is stimulated by the release of proinflammatory cytokines, including interleukin-1, interleukin-6, and tumor necrosis factor-alpha. Although sometimes referred to as an acute-phase reactant, CRP accompanies both acute and chronic inflammatory disorders [31].

[32] showed that progesterone reduced macrophage migration into the murine uterus, while [33-36] showed that estrogen, progesterone, and human chronic gonadotrophin did not affect migration of macrophage cells in guinea pigs. [37-45] showed that progesterone(p4) withdrawal is associated with the initiation of labor. The effect of P4 on immunity has been revealed, mainly at pregnancy concentrations. These effects are primarily mediated via the intracellular P4 receptors (PR), PR-A, and PR-B, which act as transcription factors [46]. Upon Pregnancy, estrogen is shown to promote uterine blood flow, myometrial growth, stimulate breast growth, and at term, promote cervical softening and expression of myometrial receptors. Also, estrogen was suggested to affect different immune cell populations in their number and function and thereby contribute to fetal tolerance [47]. Leukocytic infiltration during early Pregnancy indicated that decidual natural killer cells makeup around $30 \%$ of the uterine stromal compartment, mainly at the implantation site where they are found scattered throughout the stroma and thickly clustered around glands and spiral arteries in the uterus [48]. So, the present study aimed to evaluate the immunological effect of Lactoferrin on some cytokines, immune cells, and mucosal immunity of uterine tissue in the rat during pregnancy.

\section{Materials and Methods}

All procedures of laboratory work carried out under guidelines for biosecurity and infection control according to Guidelines for Veterinary personal biosecurity (2013) \& Australian Veterinary Infection control manual (2014).

\section{Experimental Animals}

The study was conducted on twenty-four mature female Sprague Dawley rats and six mature male rats weighing $250 \mathrm{~g}$. B. $w t$, divided into two groups, twelve female rats in each group. All animals were purchased from a laboratory animal house in, Helwan - Egypt. They were housed in separate cages in the physiology department, Faculty of veterinary medicine, Mansoura University. They were kept in a controlled environment for two weeks before the experiment for accommodation; maintained under normal condition, and rats were fed a basal control diet; water and diet 
were given ad-libitum throughout the experimental period. All females were examined for the detection of the stage of the estrus cycle by taking vaginal smear and examine it under the microscope to determine which female in the estrous phase to determine the best time of insemination according to the methods of [49].

\section{Diet and Additives}

The basal diet was prepared by the Faculty of Agriculture, Mansoura University, according to standard levels of NRC. The diet was produced in the form of pellets and was admitted to all groups of the study.

\section{Lactoferrin}

Bovine Lactoferrin (BLF), an immune-modulatory substance, was purchased from Sigma company; the commercial name is L9507 in the form of a powder that was dissolved by distilled water and was prepared to be given to twelve mature female rats (lactoferrin group) in a dose of 50 microgram $/ \mathrm{kg}$ orally by stomach tube every day before mating by one week and persisted after mating till one week according to (Yamauchi et al., 2000). Oligonucleotide primers used in SYBR Green real-time PCR: They are shown in Table 1.

Table 1: Oligonucleotide primers and probes used in SYBR Green real-time PCR.

\begin{tabular}{|c|c|c|}
\hline Target gene & Primers sequences & Reference \\
\hline RAT B-ACTIN & TCCTCCTGAGCGCAAGTACTCT & {$[7]$} \\
\hline & GCTCAGTAACAGTCCGCCTAGAA & \\
\hline IL10 & GCGGCTGAGGCGCTGTCAT & {$[15]$} \\
\hline & CGCCTT00GTAGACACCTTGGTCTTGG & \\
\hline IL1 ALPHA & GGC TAA GTT TCA ATC AGC CCT TT & {$[32]$} \\
\hline & AGG TGC TGA TCT GGG TTG GAT & \\
\hline
\end{tabular}

\section{Blood and Tissue Samples}

At different time points (5hrs, 1 day,3 days, and 7 days) after mating, blood samples were collected from retro-orbital venous plexus and separated into two parts, one for hematological assay and the other for serum separation that stored frozen until hormonal and biochemical assay. Uterine tissue samples were collected after anesthesia and slaughter of three rats of two groups at each time point and stored frozen for PCR assay and other tissue parts stored in $10 \%$ neutral buffer formaldehyde for histopathological examination.

\section{PCR}

RNA Extraction, according to (Yuan, et al. [50]): RNA extraction from tissue samples was applied using QIAamp RNeasy Mini kit (Qiagen, Germany, GmbH) when $30 \mathrm{mg}$ of the tissue sample was added to $600 \mu \mathrm{l}$ RLT buffer containing $10 \mu \mathrm{l} \beta$-mercaptothion per $1 \mathrm{ml}$. For the homogenization of samples, tubes were placed into the adaptor sets, which are fixed into the clamps of the Qiagen tissue Lyser. Disruption was performed in 2 minutes high-speed (30 Hz) shaking step. One volume of $70 \%$ ethanol was added to the cleared lysate, and the steps were completed according to the Purification of Total RNA from Animal Tissues protocol of the QIAamp Rneasy Mini kit (Qiagen, Germany, GmbH). N.B. On column DNase, digestion was done to remove residual DNA.

\section{Preparation of PCR Master Mix according to Quantitect SYBR:}

a) Oligonucleotide Primers: Primers used were supplied from Metabion (Germany) and are listed in Table 1.

b) cDNA Synthesis: RNA was reversely transcribed into cDNA using Thermo Scientific Revert Aid Reverse Transcriptase (Thermo Scientific). Where $20-\mu \mathrm{l}$ reaction containing $4 \mu \mathrm{l}$ of the $5 \mathrm{X}$ Reaction Buffer, $1 \mu \mathrm{l}$ of Revert Aid Reverse Transcriptase (200 U/ $\mu \mathrm{L}), 0.5 \mu \mathrm{l}$ of (20 U) Thermo Scientific ${ }^{\mathrm{TM}}$ RiboLock Rnase Inhibitor (\#E00381), $0.5 \mu \mathrm{l}(20 \mathrm{pmol})$ Random hexamer (\#SO142), $2 \mu \mathrm{l}$ of dNTP Mix [10 mM each (\#R0191)] $10 \mu \mathrm{l}$ of water, and $2 \mu \mathrm{l}$ of RNA template. The reaction was performed in an Applied biosystem 2720 thermal cycler. The mixture was incubated for $10 \mathrm{~min}$ at $25^{\circ} \mathrm{C}$, followed by $60 \mathrm{~min}$ at $42^{\circ} \mathrm{C}$.

c) SYBR Green rt-PCR: Primers were utilized in a 25- $\mu \mathrm{l}$ reaction containing $12.5 \mu \mathrm{l}$ of the 2x QuantiTect SYBR Green PCR Master Mix (Qiagen, Germany, GmbH), $0.5 \mu \mathrm{l}$ of each primer of 20 pmol concentration, $10.5 \mu \mathrm{l}$ of water, and $1 \mu \mathrm{l}$ of cDNA template. The reaction was performed in a Stratagene MX3005P real-time PCR machine. A primary denaturation step was done at $940 \mathrm{C}$ for $15 \mathrm{~min}$, followed by 40 cycles of $94^{\circ} \mathrm{C}$ for $15 \mathrm{sec}$., $60^{\circ} \mathrm{C}$ for $30 \mathrm{sec}$. and $72^{\circ} \mathrm{C}$ for $30 \mathrm{sec}$. A Dissociation curve was performed for one cycle, including $940 \mathrm{C}$ for $1 \mathrm{~min}$., $60^{\circ} \mathrm{C}$ for $1 \mathrm{~min}$., and $94^{\circ} \mathrm{C}$ for $1 \mathrm{~min}$.

d) Analysis of the SYBR Green rt-PCR Results: Amplification curves and ct values were determined by the Stratagene MX3005P software. To estimate the variation of gene expression on the RNA of the different samples, the CT of each sample was compared with that of the positive control group according to the " $\Delta \Delta \mathrm{Ct}$ " method stated by [51].

\section{Biochemical Assay}

1-Estrogen: Estrogen was diagnostic by using IMMULITE and IMMULITE 1000 Analyzer for the quantitative measurement of Estradiol in serum, as an aid in the differential diagnosis of amenorrhea, and monitoring8 of ovulation induction with and without stimulating in Assisted Reproductive Technology (ART) according to [52].

2-progesterone: Progesterone was diagnostic by using IMMULITE and IMMULITE 1000 Analyzer for the quantitative measurement of progesterone in serum, as an aid in the differential diagnosis of amenorrhea, and monitoring of ovulation induction with and without stimulating in Assisted Reproductive Technology (ART) according to [53]. 
3- TAC (Total Antioxidant Capacity): Total antioxidant capacity is measured by the colorimetric determination method by ready-made diagnostic kits provided by Bio-diagnostic, according to [54].

4- TNF $\alpha$ (Tumor Necrosis Factor): TNF $\alpha$ was estimated by using ready-made Rat Tumor Necrosis Factor- $\alpha$ (TNF $\alpha$ ). ELISA Kit presented by Quantikine Company according to [55]

5- CRP (C- Reactive Protein): The rapid latex agglutination test is for the qualitative screening and quantitative determination of C-Reactive Protein (CRP) in serum presented by ATLAS MEDICAL LATEX Kit, according to [56].

\section{Tissue Sampling}

Both uterine horns were excised from all pregnant rats and one sample from each horn was taken and fixed immediately in $10 \%$ neutral buffered formalin solution. All specimens were routinely processed in ascending grades of ethyl alcohol (80\%, 90\%, 100\%), cleared in xylene, and embedded in paraffin wax to prepare $5 \mu \mathrm{m}$ thick paraffin sections. Sections of $5 \mu \mathrm{m}$ thickness were cut and picked up on uncoated slides, dried, deparaffinized with xylene (3x3minutes) and rehydrated with graded alcohol (5x2minutes), washed and stained with H\&E according to [57], and stained with Giemsa stain to determine eosinophil cell count in uterine tissue sections. Uterine sections from day 7 of gestation were additionally stained with Masson's trichrome. The stained sections were dehydrated in absolute ethyl alcohol, cleared in xylene, and mounted with Mount-Quick liquid cover glass medium to the surface of the slides. Histological changes were examined by light microscopy (binocular, Olympus). Histological pictures were picked up using a Digital camera (Canon 5 megapixels, 3.2x optical zoom).

\section{Histopathological Examination and Statistical Analysis}

The data of histopathological examination of morphometric measurements of epithelial height and diameter of uterine glands were subjected to student T-test to differentiate between control and lactoferrin treated group to compare the difference between means. Data were expressed as means \pm standard errors. The difference between means was considered significant when $(\mathrm{P}<$ 0.05). The remaining data obtained for rats of the two experiments were expressed as means \pm SD. Statistical Analysis of data was carried out by the computer package program (SPSS,1994) version 16, using the two-way Analysis of variance M-ANOVA between variables at group level and time level followed by Duncans Multiple Range Test (DMRT) for testing the significant differences between variables [58].

\section{Results}

\section{Effect of Lactoferrin on Total Leukocytic Count $\left(\mathrm{WBCS} \times 10^{3} / \mu \mathrm{l}\right)$}

As shown in Table 2 results indicated an increase in Wbcs at $5 \mathrm{hrs}$, 1day, and 3 days after mating in the lactoferrin group compared with the control group at the same time.

Table 2: Effect of Lactoferrin on total leukocytic count (WBCS $\times 10^{3}$ $/ \mu \mathrm{l})$.

\begin{tabular}{|c|c|c|}
\hline \multicolumn{3}{|c|}{ GROUPS } \\
\hline TIME & Control & Lactoferrin \\
\hline 5HRS & $7.00 \pm 1.15^{\mathrm{Cd}}$ & $10.43 \pm 0.55^{\mathrm{Ac}}$ \\
\hline 1DAY & $9.23 \pm .72^{\mathrm{Cc}}$ & $10.7 \pm 0.72^{\mathrm{Ab}}$ \\
\hline 3DAYS & $10.33 \pm 0.44^{\mathrm{Ba}}$ & $11.00 \pm 0.57^{\mathrm{Aa}}$ \\
\hline 7DAYS & $9.47 \pm 0.6^{\mathrm{Ab}}$ & $7.00 \pm 0.92^{\mathrm{Bb}}$ \\
\hline
\end{tabular}

\section{Effect of Lactoferrin on Neutrophil\%}

As shown in Table 3, results indicated an increase in neutrophil percent in the lactoferrin group at 5hrs, 3 days, and 7 days after mating compared with the control group.

Table 3: Effect of Lactoferrin on neutrophil\%.

\begin{tabular}{|c|c|c|c|}
\hline \multicolumn{3}{|c|}{ Groups } \\
\hline Time & Control & Lactoferrin & Significance \\
\hline 5HRS & $72.00 \pm 4.93^{\mathrm{Bc}}$ & $74.40 \pm 0.29^{\mathrm{Ba}}$ & Not significant \\
\hline 1 DAY & $75.00 \pm 2.65^{\mathrm{Ac}}$ & $73.20 \pm 0.93^{\mathrm{Bb}}$ & significant $\mathrm{p}<0.05$ \\
\hline 3 DAYS & $69.67 \pm 0.88^{\mathrm{Ca}}$ & $75.23 \pm 1.91^{\mathrm{Aa}}$ & significant $\mathrm{p}<0.05$ \\
\hline 7 DAYS & $69.33 \pm 1.20^{\mathrm{Cb}}$ & $75.03 \pm 0.52^{\mathrm{Ab}}$ & significant $\mathrm{p}<0.05$ \\
\hline
\end{tabular}

\section{Effect of Lactoferrin on Lymphocyte\%}

As shown in Table 4, results demonstrated a decrease in lymphocyte percent in the lactoferrin group at 5hrs, 1 day, 3 days, and7 days after mating.

Table 4: Effect of Lactoferrin on lymphocyte\%.

\begin{tabular}{|c|c|c|c|}
\hline \multicolumn{4}{|c|}{ Groups } \\
\hline Time & Control & Lactoferrin & Significance \\
\hline 5HRS & $19.00 \pm 5.20^{\mathrm{Ac}}$ & $16.37 \pm 0.82^{\mathrm{Ca}}$ & significant $\mathrm{p}<0.05$ \\
\hline 1 DAY & $18.67 \pm 1.33^{\mathrm{Ad}}$ & $17.97 \pm 0.58^{\mathrm{Ba}}$ & significant $\mathrm{p}<0.05$ \\
\hline 3 DAYS & $20.00 \pm 1.00^{\mathrm{Ab}}$ & $16.23 \pm 1.60^{\mathrm{Cb}}$ & significant $\mathrm{p}<0.05$ \\
\hline 7 DAYS & $21.67 \pm 1.67^{\mathrm{Aa}}$ & $17.23 \pm 0.88^{\mathrm{Bb}}$ & significant $\mathrm{p}<0.05$ \\
\hline
\end{tabular}

\section{Effect of Lactoferrin on Eosinophil\%}

As shown in Table 5, results indicated that the eosinophil percent increase in Lactoferrin at $5 \mathrm{hrs}, 1$ day, and 7 days. 
Table 5: Effect of Lactoferrin on eosinophil\%.

\begin{tabular}{|c|c|c|c|}
\hline \multicolumn{3}{|c|}{ Groups } \\
\hline TIME & Control & Lactoferrin & Significance \\
\hline 5 HRS & $2.67 \pm 0.33^{\mathrm{Ca}}$ & $4.90 \pm 0.35^{\mathrm{Aa}}$ & significant $\mathrm{p}<0.05$ \\
\hline 1 DAY & $3.67 \pm 0.33^{\mathrm{Bb}}$ & $4.03 \pm 0.99^{\mathrm{Ab}}$ & significant $\mathrm{p}<0.05$ \\
\hline 3 DAYS & $4.00 \pm 0.00^{\mathrm{Ad}}$ & $3.70 \pm 0.36^{\mathrm{Ba}}$ & significant $\mathrm{p}<0.05$ \\
\hline 7 DAYS & $3.33 \pm 0.33^{\mathrm{Bb}}$ & $4.00 \pm 0.66^{\mathrm{Ac}}$ & significant $\mathrm{p}<0.05$ \\
\hline
\end{tabular}

\section{Effect of Lactoferrin on Basophil\%}

As shown in Table 6, results indicated that basophil decrease in the lactoferrin group at 5hrs, 1 day, and 7 days.

Table 6: Effect of Lactoferrin on basophil\%.

\begin{tabular}{|c|c|c|c|}
\hline \multicolumn{3}{|c|}{ GROUPS } \\
\hline TIME & Control & Lactoferrin & Significance \\
\hline 5 HRS & $1.33 \pm 0.33^{\mathrm{Ac}}$ & $1.00 \pm 0.01^{\mathrm{Ba}}$ & significant $\mathrm{p}<0.05$ \\
\hline $1 \mathrm{DAY}$ & $1.67 \pm 0.33^{\mathrm{Aa}}$ & $1.57 \pm 0.57^{\mathrm{Ab}}$ & Not significant \\
\hline 3 DAYS & $1.00 \pm 0.01^{\mathrm{Ba}}$ & $1.00 \pm 0.01^{\mathrm{Ba}}$ & Not significant \\
\hline 7 DAYS & $1.33 \pm 0.33^{\mathrm{Ac}}$ & $1.00 \pm 0.01^{\mathrm{Ba}}$ & significant $\mathrm{p}<0.05$ \\
\hline
\end{tabular}

\section{Effect of Lactoferrin on Monocyte\%}

As shown in Table 7, results indicated that the monocyte percent decrease in the lactoferrin group at $5 \mathrm{hrs}$, 1 day, 3 days, and 7 days.

Table 7: Effect of Lactoferrin on monocyte \%.

\begin{tabular}{|c|c|c|c|}
\hline \multicolumn{3}{|c|}{ GROUPS } \\
\hline TIME & Control & Lactoferrin & Significance \\
\hline 5 HRS & $5.00 \pm 0.58^{\mathrm{Aa}}$ & $3.33 \pm 0.64^{\mathrm{Bb}}$ & significant $\mathrm{p}<0.05$ \\
\hline 1 DAY & $4.33 \pm 0.88^{\mathrm{Ab}}$ & $3.23 \pm 0.09^{\mathrm{Bc}}$ & significant $\mathrm{p}<0.05$ \\
\hline 3 DAYS & $5.00 \pm 0.58^{\mathrm{Aa}}$ & $3.83 \pm 0.50^{\mathrm{Ba}}$ & significant $\mathrm{p}<0.05$ \\
\hline 7 DAYS & $4.33 \pm 0.33^{\mathrm{Ab}}$ & $2.50 \pm 0.35^{\mathrm{Ca}}$ & significant $\mathrm{p}<0.05$ \\
\hline
\end{tabular}

\section{Effect of Lactoferrin on Estrogen(ng/ml)}

As shown in Table 8, results indicated that estrogen decrease in the lactoferrin group at $5 \mathrm{hrs}$ and 1 day when compared to the control group.

Table 8: Effect of lactoferrin on estrogen $(\mathrm{ng} / \mathrm{ml})$.

\begin{tabular}{|c|c|c|c|}
\hline \multicolumn{3}{|c|}{ GROUPS } \\
\hline TIME & Control & Lactoferrin & Significance \\
\hline 5HRS & $48.43 \pm 0.86^{\mathrm{Aa}}$ & $45.90 \pm 2.38^{\mathrm{Ba}}$ & significant $\mathrm{p}<0.05$ \\
\hline 1 DAY & $45.83 \pm 2.88^{\mathrm{Ba}}$ & $40.97 \pm 1.14^{\mathrm{Cb}}$ & significant $\mathrm{p}<0.05$ \\
\hline 3 DAYS & $41.23 \pm 1.13^{\mathrm{Ca}}$ & $41.27 \pm 1.82^{\mathrm{Ca}}$ & Not significant \\
\hline 7 DAYS & $46.60 \pm 2.31^{\mathrm{Ac}}$ & $47.53 \pm 2.44^{\mathrm{Ab}}$ & Not significant \\
\hline
\end{tabular}

\section{Effect of Lactoferrin on Progesterone (ng/ml)}

As shown in Table 9, results indicated an increase in progesterone hormone in the lactoferrin group at 5hrs, 1 day, 3 days, and 7 days after mating when compared to the control group.
Table 9: Effect of Lactoferrin on progesterone (ng/ml).

\begin{tabular}{|c|c|c|c|}
\hline \multicolumn{4}{|c|}{ GROUPS } \\
\hline TIME & Control & Lactoferrin & Significance \\
\hline 5HRS & $39.47 \pm 0.69^{\mathrm{Cb}}$ & $67.87 \pm 1.16^{\mathrm{Ab}}$ & significant $\mathrm{p}<0.05$ \\
\hline 1 DAY & $48.43 \pm 0.67^{\mathrm{Ca}}$ & $60.60 \pm 1.29^{\mathrm{Ba}}$ & significant $\mathrm{p}<0.05$ \\
\hline 3 DAYS & $57.83 \pm 0.38^{\mathrm{Bc}}$ & $69.17 \pm 1.73^{\mathrm{Aa}}$ & significant $\mathrm{p}<0.05$ \\
\hline 7 DAYS & $58.67 \pm 1.82^{\mathrm{Bb}}$ & $65.53 \pm 1.65^{\mathrm{Ab}}$ & significant $\mathrm{p}<0.05$ \\
\hline
\end{tabular}

\section{Effect of Lactoferrin on Total Antioxidant Capacity (TAC) $(\mu \mathrm{mol} / \mathrm{L})$ :}

As shown in Table 10, results indicated a decrease in the lactoferrin group at 5hrs, 1 day, 3 days, and 7 days when compared with the control group.

Table 10: Effect of Lactoferrin on total antioxidant capacity (TAC) $(\mu \mathrm{mol} / \mathrm{L})$.

\begin{tabular}{|c|c|c|c|}
\hline \multicolumn{3}{|c|}{ GROUPS } \\
\hline TIME & Control & Lactoferrin & Significance \\
\hline 5 HRS & $0.58 \pm 0.01^{\mathrm{Aa}}$ & $0.40 \pm 0.01^{\mathrm{Bb}}$ & Not significant \\
\hline 1 DAY & $0.51 \pm 0.02^{\mathrm{Ab}}$ & $0.49 \pm 0.01^{\mathrm{Ac}}$ & Not significant \\
\hline 3 DAYS & $0.49 \pm 0.01^{\mathrm{Ac}}$ & $0.38 \pm 0.02^{\mathrm{Bb}}$ & significant $\mathrm{p}<0.05$ \\
\hline 7 DAYS & $0.49 \pm 0.02^{\mathrm{Ac}}$ & $0.42 \pm 0.02^{\mathrm{Ba}}$ & significant $\mathrm{p}<0.05$ \\
\hline
\end{tabular}

Effect of Lactoferrin on Tumor Necrosis Factor (TNF) (pg/ml)

As shown in Table 11, results indicated an increase in TNF at 5hrs, 1 day, 3 days, and 7 days in the lactoferrin group when compared to the control group.

Table 11: Effect of Lactoferrin on tumor necrosis factor (TNF) (pg/ml).

\begin{tabular}{|c|c|c|c|}
\hline \multicolumn{3}{|c|}{ GROUPS } \\
\hline TIME & Control & Lactoferrin & Significance \\
\hline 5 HRS & $50.90 \pm 0.80^{\mathrm{Ba}}$ & $60.20 \pm 1.54^{\mathrm{Ad}}$ & significant $\mathrm{p}<0.05$ \\
\hline 1 DAY & $50.37 \pm 0.99^{\mathrm{Bb}}$ & $69.67 \pm 1.42^{\mathrm{Ab}}$ & significant $\mathrm{p}<0.05$ \\
\hline 3 DAYS & $48.77 \pm 3.13^{\mathrm{Bc}}$ & $69.27 \pm 5.66^{\mathrm{Ac}}$ & significant $\mathrm{p}<0.05$ \\
\hline 7 DAYS & $40.03 \pm 0.75^{\mathrm{Ca}}$ & $73.20 \pm 2.89^{\mathrm{Aa}}$ & significant $\mathrm{p}<0.05$ \\
\hline
\end{tabular}

\section{Effect of Lactoferrin on C-Reactive Protein (mg/L)}

As shown in Table 12, results indicated an increase in $\mathrm{C}$ reactive protein in the lactoferrin group at $5 \mathrm{hrs}$, 1 day, 3 days, and 7 days when compared to the control group.

Table 12: Effect of Lactoferrin on C-reactive protein (mg/L).

\begin{tabular}{|c|c|c|c|}
\hline \multicolumn{3}{|c|}{ GROUPS } \\
\hline TIME & Control & Lactoferrin & Significance \\
\hline 5 HRS & $6.50 \pm 0.55^{\mathrm{Ba}}$ & $12.33 \pm 1.10^{\mathrm{Ac}}$ & significant $\mathrm{p}<0.05$ \\
\hline 1 DAY & $6.03 \pm 0.15^{\mathrm{Bc}}$ & $12.57 \pm 1.41^{\mathrm{Ab}}$ & significant $\mathrm{p}<0.05$ \\
\hline 3 DAYS & $6.27 \pm 0.22^{\mathrm{Bb}}$ & $12.53 \pm 1.53^{\mathrm{Ab}}$ & significant $\mathrm{p}<0.05$ \\
\hline 7 DAYS & $6.70 \pm 0.46^{\mathrm{Ba}}$ & $13.20 \pm 1.23^{\mathrm{Aa}}$ & significant $\mathrm{p}<0.05$ \\
\hline
\end{tabular}


Effect of Lactoferrin on IL1a and IL10 by Real-Time PCR:

As illustrated from Figure 1, results indicated an increase in interleukin $1 \mathrm{~A}$ in the lactoferrin group at $5 \mathrm{hrs}, 1$ day, and 3 days after mating when compared to the control group. At the same time, results indicated an increase in interleukin 10 in the lactoferrin group at $5 \mathrm{hrs}$ and 1 day after mating but decreased at 3 days and 7 days when compared with the control group.

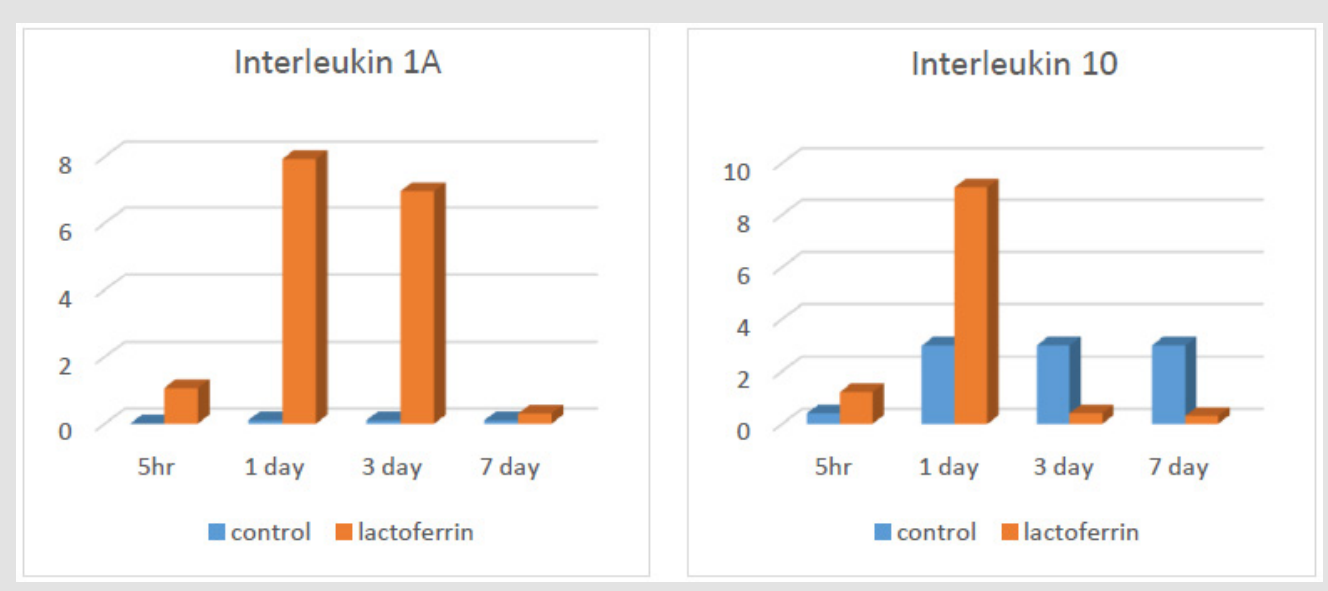

Figure 1: Effect of Lactoferrin on IL1a and IL10 by real-time PCR.

\section{Histopathological Analysis for Rat Uterus}

\section{Rat Uterus After 5 Hours of Gestation}

As illustrated from Figure 2, the microscopic picture shows rat uterus after 5 hours of gestation shows heavy eosinophils infiltration in superficial endometrium (arrows) (A, B) and in between uterine glands (g) (arrows). Few stromal cell density and very few eosinophils' infiltrations are seen in superficial endometrium (arrows), and heavy eosinophils infiltrations are seen in between uterine glands (g) (arrows) in Lactoferrin treated rats I. Control (slide A and B), Lactoferrin group (C and D).

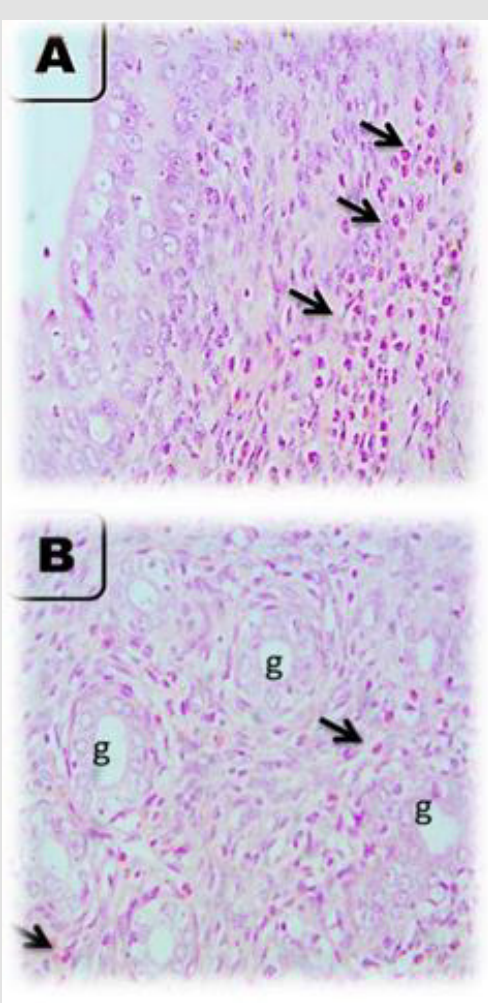

Control group : slide A, B,
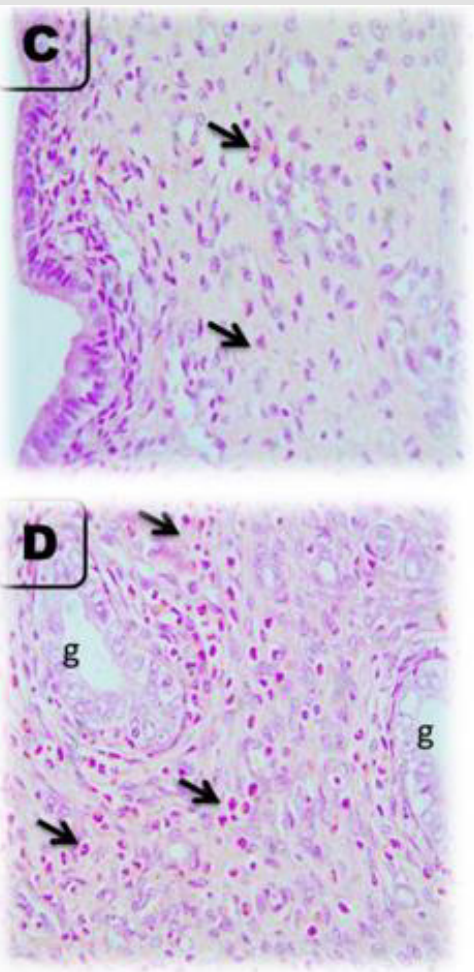

Lactoferrin group: slide C, D

Figure 2: Microscopic picture shows rat uterus after 5 hours of gestation. 


\section{Rat Uterus at 1 Day of Gestation}

As illustrated from Figure 3, the microscopic picture shows rat uterus at 1 day of gestation shows focal PMNs infiltration in superficial endometrium (black arrows) (A) and fewer eosinophils between the uterine glands ( $\mathrm{g}$ ) than after 5 hours (orange arrows) (B) in control rats. Very few eosinophils' infiltrations are seen in superficial endometrium (orange arrows) (C), and between uterine glands (g) (orange arrows) (D) in Lactoferrin treated rats. H\&E, $\mathrm{X}$ : 400.Note: density of uterine glands increased in Lactoferrin treated rats (D) when compared with (B). H\&E. The Control group presented in (slide $\mathrm{A}$ and $\mathrm{B}$ ) and Lactoferrin group presented in slide (C and D).
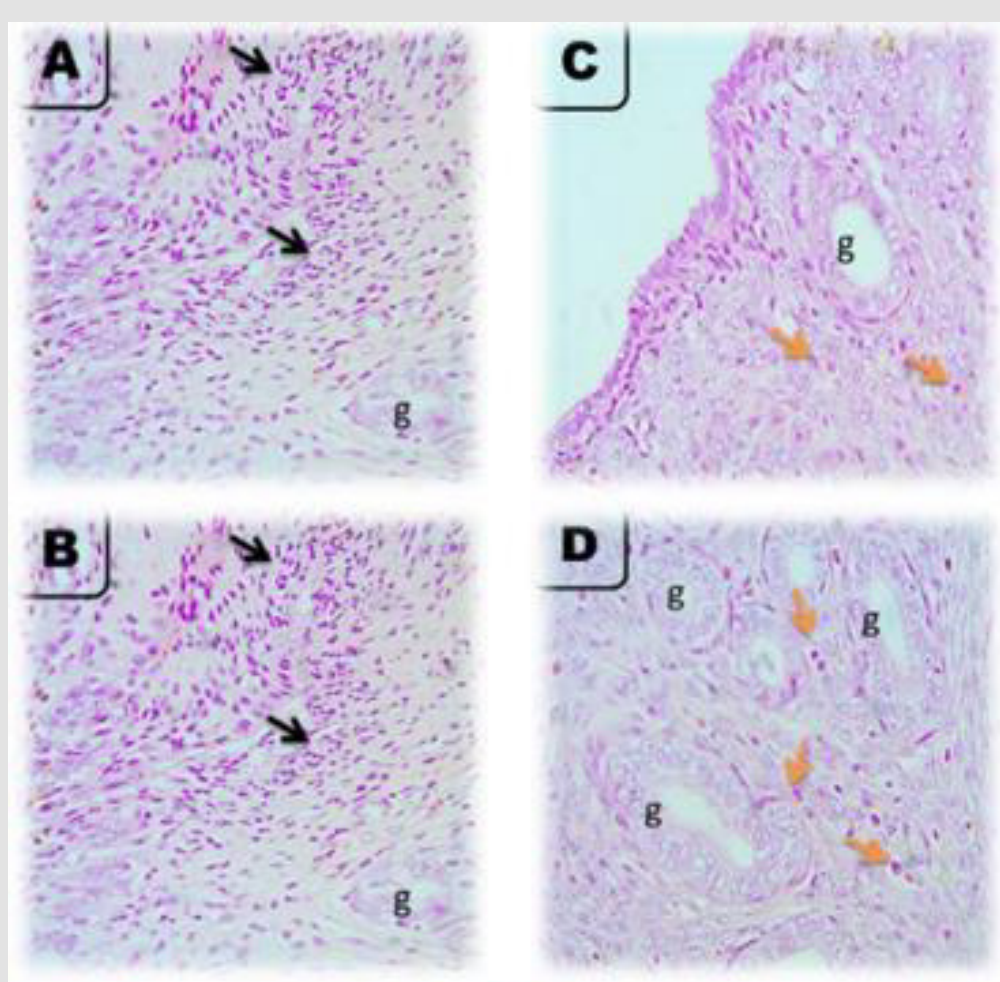

\section{Control group : slide A, B, Lactoferrin group : slide C, D}

Figure 3: Microscopic picture shows rat uterus at 1 day of gestation.

\section{Rat Uterus at 3 Days of Gestation}

As illustrated from Figure 4, the microscopic picture shows rat uterus at 3 days of gestation shows minimal leukocytic cells infiltration in superficial endometrium (A) and between the uterine glands (orange arrows) (g) (B) in control rats. Few eosinophils' infiltrations are seen in superficial endometrium (orange arrows) (C), and between uterine glands (g) (orange arrows) (D) in Lactoferrin treated rats. $\mathrm{H}$ and E. Microscopic picture shows rat uterus at 3 days of gestation shows eosinophils infiltration in the myometrium (arrows) (A) in control rats and Lactoferrin treated rats (C). Uterine glands in control (B) and Lactoferrin treated $\operatorname{rats}(\mathrm{D})$.

\section{Rat Uterus at 7 Days of Gestation}

As illustrated from Figure 5, the microscopic picture shows rat uterus at 7 days of gestation shows superficial endometrium (A) and uterine glands ( $\mathrm{g}$ ) with few eosinophils' infiltration (orange arrows) (B) in control rats. Few eosinophils' infiltrations are not seen in superficial endometrium (C) but seen between uterine glands (g) (orange arrows) (D) in Lactoferrin treated rats. Note: density and diameter of uterine glands (g) increased in (D) in Lactoferrin treated rats, H\&E. Control (slide A and B), Lactoferrin group (C and D).

\section{Effects of Lactoferrin Administration to Pregnant Rat on Eosinophil Count in Uterine Tissue at a Different Time (5hrs, 1day, 3days, and 7 days) of Pregnancy}

The effects of lactoferrin administration to pregnant rats on eosinophil count in uterine tissue at a different time (5hrs, 1day, 3days, and 7 days) of Pregnancy is shown and summarized in Figure 6. 

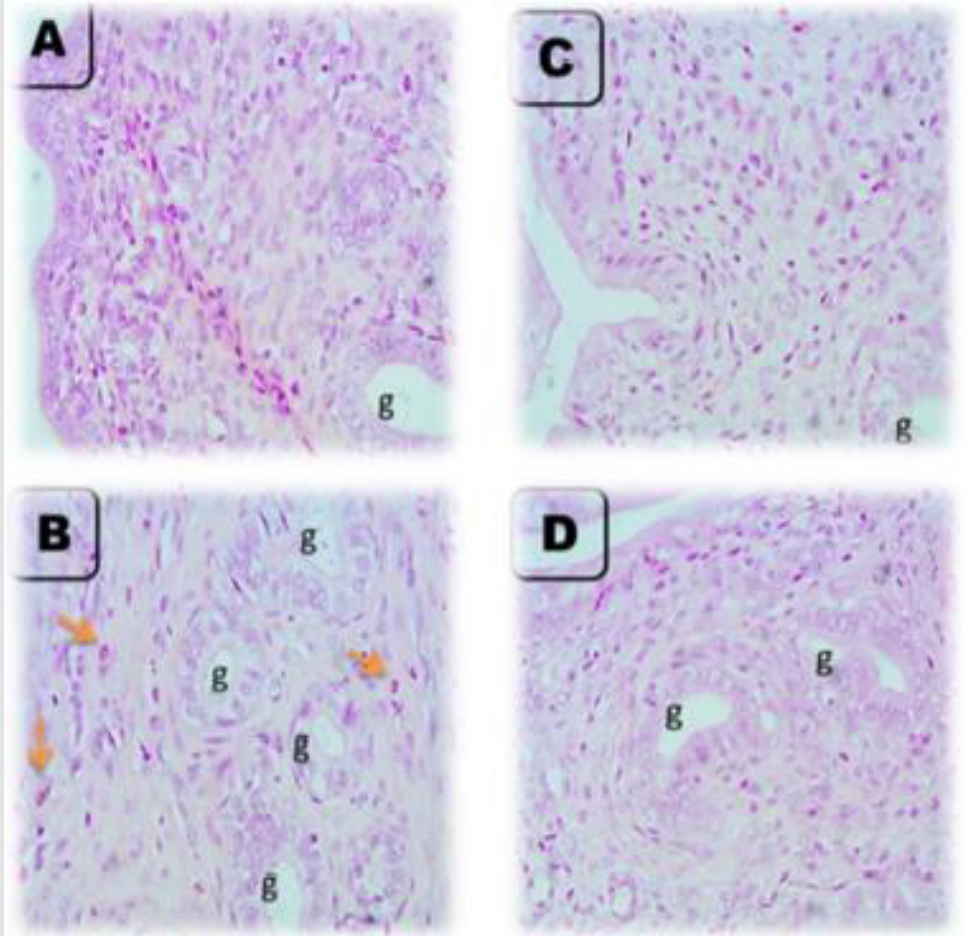

Lacto group : slide A, B,

Lactoferrin group: slide C, D

Figure 4: Microscopic picture shows rat uterus at 3 days of gestation.
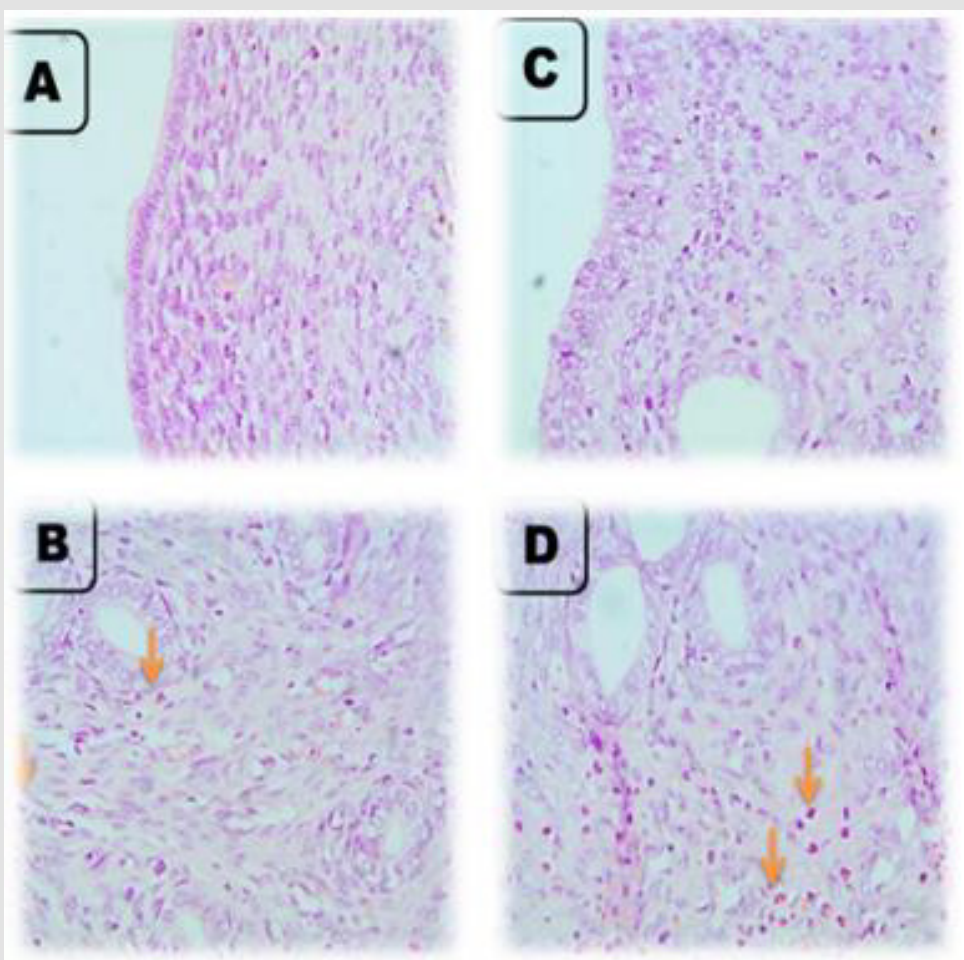

Control group : slide A, B,

Lactoferrin group : slide C, D

Figure 5: Microscopic picture shows rat uterus at 7 days of gestation. 


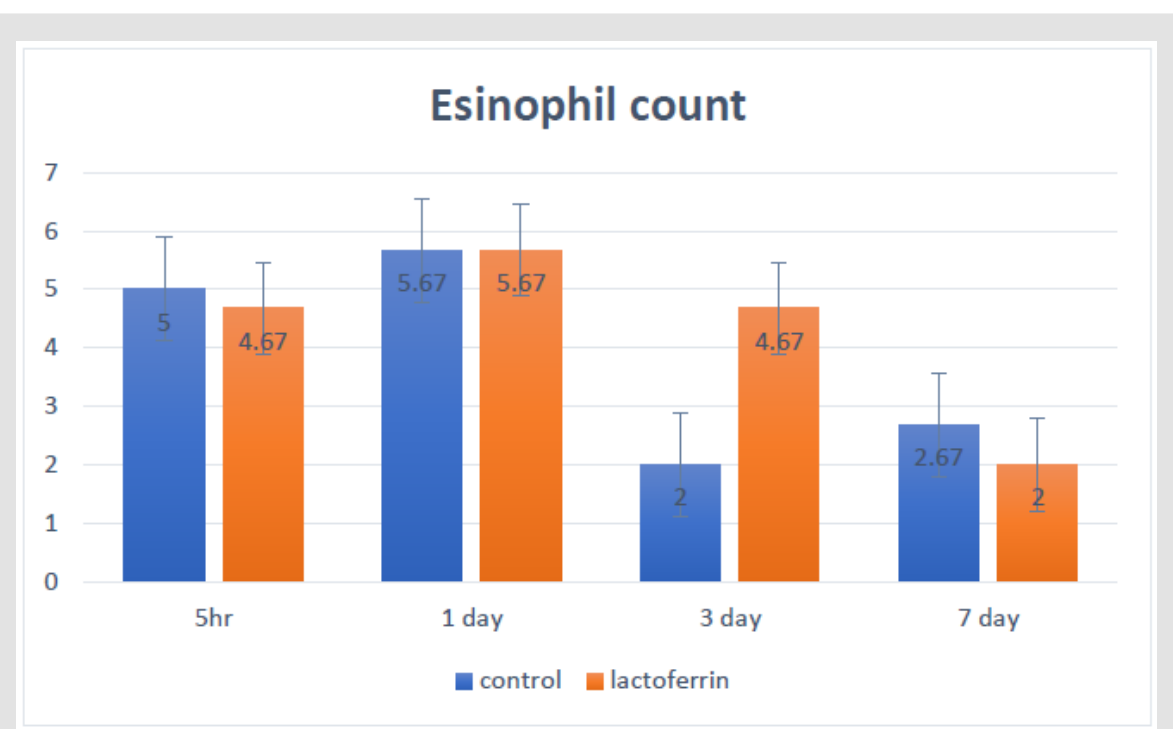

Figure 6: Effects of lactoferrin administration to pregnant rat on eosinophil count in uterine tissue at different time (5hrs, 1day, 3 days and 7 days) of Pregnancy

\section{Discussion}

From the results, we should remember that we are dealing mainly with concentrations of a number of immunity markers either wbcs in plasma or immunity markers, hormones and cytokines in serum to detect effect of LF on immunity mainly during early period of pregnancy. Results of the present investigation were recorded in (Tables 2-7) showed that white blood cells number increased at 5 hrs and 3 days after insemination and decreased at 7 days after insemination in the lactoferrin group when compared with the control group. Lf was a natural compound of mammalian secretions which have a protective effects range from antimicrobial activities against variety of pathogens, including bacteria, viruses, fungi and parasites, to anti-inflammatory effect. Its functions rely not only on the capacity of Lf to bind iron but also on its immunomodulatory effect by its cellular and molecular mechanisms with both host and pathogen. Lf can interact with antigen presenting cells, reduce excessive inflammation and stimulate host immune responses, as well as identifying cell targets and receptors and this was important in the maintenance of immune system homeostasis [59]. Neutrophils increased at $5 \mathrm{hrs}$, 3 days, and 7 days after insemination, while basophil and eosinophil increased at 5hrs, 1 day, and 7 days after insemination in the lactoferrin group.

While, Lymphocyte and monocyte showed a significant decrease in the lactoferrin group at 5hrs, 1 day, 3 days, and 7 days after insemination. This result agreed with [60], who showed that Lactoferrin had a role in regulating innate and adaptive immune response, regulating the secretion of cytokines and regulated growth, differentiation, and activation of different leukocyte cells and so increased the number of circulated leukocytes. This agrees with [61], who showed that both monocytes and granulocytes increased and immune systems activated during Pregnancy in the rat. [62] reported that Lactoferrin regulated the immune system by stimulating endometrial and stromal cell proliferation and stimulating immune cells against antigen as well as [63] reported that Lactoferrin increased recruitment of neutrophil in mice circulation. Besides, [64] recorded that Lactoferrin increased the number of natural killer cells and modulated myelopoiesis with increased phagocytosis against a specific antigen. In the same respect, [65] showed that WBCs increased during rat pregnancy, and this was inconsistent with the significant increase in the number of white blood cells as presented in (Table 2).

Estrogen increased in the lactoferrin group, particularly at 7 days after insemination, and showed decreased at $5 \mathrm{hrs}$ and 1 day after insemination. Estrogen was considered an immune modulator substance that could improve the immune response of the female reproductive tract in rodents, as shown by [66]. This agreed with (Hamid et al. 2012) showed that rats implantation period was initiated on day 5 and completed by day 7 of the pregnancy and during this implantation period, the dominant hormone modulator to morohological and functional changes were estrogen and progesterone and this may explain why estrogen increased at our study at 7 days taking into consideration the difference between species as difference between rat and human in time of endometrium changes and hormones secretion as shown [67] showed that estrogen played a pivotal role in early Pregnancy in mice as, during the first two days after insemination, the preovulatory estrogenstimulated proliferation of the luminal and glandular epithelial cells in addition to potentiated with progesterone hormone that secreted from corpus luteum and stimulated stromal cell proliferation on 4 days which was the day of the implantation process. Furthermore, [68] showed that there was a close relationship between estrogen 
and Lactoferrin as an estrogen-regulated expression of Lactoferrin in the endometrial epithelium of rat, particularly along all stages of the estrus cycle as well as lactoferrin levels changed with the change in estrogen level and so this could explain the increase in estrogen hormone in lactoferrin group after insemination.

Progesterone increased at 5hrs, 3 days, and 7 days in the lactoferrin group compared to the control group, as showed in Table 10. [69] reported that progesterone hormone inhibited estrogen hormone and decreased lactoferrin gene expression in uterine epithelial and stromal cells by controlling progesterone receptor and affecting estrogen receptors in vitro using uterine rat tissue. Also, [70] reported that progesterone was secreted in hamsters at the preovulatory stage from an extra luteal tissue source for allowed characteristics appearance of estrus behavior, and this could explain the increase in progesterone hormone in the lactoferrin group. Total Antioxidant Capacity(TAC) increased in the lactoferrin group at 1 day after insemination when compared to the control group as showed in Table 10 and this agrees with [71] who showed that Lactoferrin (LF) was believed to be safer than the drugs currently used for hypertension treatment due to its antioxidant effect. It has been reported that two weeks of lactoferrin supplementation has been able to increase the hydrophilic antioxidant capacity in healthy humans [72]. Besides, [73] suggested that Lactoferrin contributed to oxidoreductive reactions at the cell membrane, and LF had an antioxidant effect on red blood cells through inhibition of lipid peroxidation and hemolysis. In the same respect, LF was an important specialized iron scavenger, and its antioxidant activity was most likely related to its ability to bind ferrous and ferric ions. Thus, LF may inhibit the iron-catalyzed formation of hydroxyl radicals.

Tumor necrosis factor (TNF) decreased at 3 days and then increased at 5hrs, 1 day, and 7 days in the lactoferrin group as presented in Table 11. This increase may be due to secretion of TNF at early gestation as that different cytokine profiles might be beneficial or harmful at different stages of Pregnancy as TNF-a which was proinflammatory cytokines seem to be crucial during the implantation process, whereas high levels of these cytokines may be harmful later in Pregnancy. Also, showed that tumor necrosis factor was multi potent cytokines and had an essential role during early Pregnancy by the stimulated embryo and placental growth. In contrast, revealed that TNF had an adverse impact on Pregnancy and inhibited blastocyst growth in the rat. This conflicted impact was shown by reported that the timing of secretion, the concentration of TNF, and stimulatory signals directed TNF to be either useful or harmful toward Pregnancy. Nakashima 2012 suggested that stimulation of Th 1 dominance directed TNF to stimulate lymphokine-activated killer cells that destructed trophoblast cells and caused pregnancy loss. Moreover, Clark 1998 suggested that TNF stimulated maternal immune rejection to the embryo through the affected blood supply by applying vasculitis. This data could explain the significant increase in TNF in the lactoferrin group, particularly at 5hrs, 1 day, 3 days, and 7 days of Pregnancy.

C-Reactive Protein (CRP) increased at 5hrs, 1 day, 3 days, and 7 days of Pregnancy in the lactoferrin group when compared to the control group, as shown in Table 12. This in agreement who found a slight rise in the CRP values throughout Pregnancy, and who detected maximal concentrations of CRP at 24-48 hours after the inducing stimulus or infection and so may be increased due to presence of sperm and then the presence of embryo as immune response. Moreover, CRP increased in inflammation and applied a proinflammatory function and stimulated secretion of cytokines and granulocyte-macrophage colony-stimulating factor as well as had anti-inflammatory functions as prevented migration and adhesion of neutrophil to endothelial cells to provide immune tolerance and aided in implantation and this meant that presence of embryo or sperm caused inflammatory response and stimulated secretion of CRP. Interleukin 1a (IL1A) increased at 5hrs, 1day, and 3 days in the lactoferrin group, as showed in Figure 1. This in agreement with, who showed that the interleukin1(IL1) family as IL1alpha and IL1 b secreted by early embryonic signals and aided in the preparation of a receptive maternal endometrium and may play an important role in embryo implantation.

Interleukin 10 increased in the lactoferrin group, particularly at 5 hrs and 1 day of Pregnancy as shown in Figure 1. This in agreement with recorded that an up-regulation of anti-inflammatory IL-10 was found after lactoferrin (LF) administration in rats with colitis. Moreover, reported that bovine LF regulated cytokines production by splenocytes of obstructive jaundice rats. Also, LF enhanced the secretion of the anti-inflammatory cytokines IL-10 and IL-4 and reduced colitis in rats. Interleukin 10 entered in the initial formation of the fetus and supported implantation during the early period of Pregnancy as proved by Tewari 2009 that IL-10 role in Pregnancy was a potent protector against vascular dysfunction that was associated with hypertension and inflammation during Pregnancy as contributing to the regulation of maternal immune tolerance during Pregnancy and helped in the extra villous trophoblast and endothelial cell formation. Besides, illustrated that interleukin 10 in mice reached high levels in the first and second trimester of Pregnancy for improving placental growth and supporting trophoblast invasion. Histopathological examination of uterine tissue specimens presented in Figures 2-5 showed that the rat uterus was formed of three layers; endometrium, myometrium, and perimetrium. The endometrial glandular epithelium was a tall simple columnar with rounded basal nuclei. Few Polymorphonuclear Cells (PMNs) were seen in the lumen of the uterus and uterine glands.

The stroma contained spindle-shaped stromal cells and blood vessels. The myometrium was formed of inner circular and outer longitudinal smooth muscle layers with numerous blood 
capillaries in the perimetrium. Histopathological examination after administration of Lactoferrin to female rats revealed that there was an increase in eosinophilic and neutrophil infiltration in endometrium and myometrium, increased stromal cells, and increased in epithelial cell thickness and folding at 5hrs, 1 day, 3 days, and 7 days after insemination. This agreed showed that there was a dramatic increase in cellular proliferation, endometrial tissues proliferation neovascularization, and blood flow during early rat pregnancy. Also, Guerra-Infante 1999 showed that neutrophil cells increased in the count but decreased in phagocytic activity during Pregnancy. Moreover, there was an increase in a blood vessel with decreased congestion and an increase in the number and diameter of the uterine gland when compared with the control group. This may provide nutrition to the embryo at early Pregnancy as the obtained results are declared and presented in Figures 2-5. This result inconsistency with Filant and Spencer, 2013 showed that uterine glands and blood vessels supported embryo with essential substances like proteins and sugars during early Pregnancy for providing the fetus with adequate nutrition. This could explain the increase of uterine gland number in early Pregnancy, particularly in the lactoferrin group, as shown in Figures 2-5.

In early pregnant women and rats, demonstrated that decidual cells differentiated and clumped together to form masses around cells to be in direct contact allowing the transportation of food between mother and fetus. The increase in stromal cells and epithelial cell proliferation in the lactoferrin group agreed who showed that Lactoferrin had a stimulatory and inhibitory effect on cell division and proliferation as it stimulated growth and division of somebody cells and inhibited others as mammary epithelial cells, fibroblasts, and tumor cells that may be according to the type of cells with unknown mechanism. In the same respect, demonstrated that estrogen and progesterone regulated expression of Lactoferrin in rat uterine tissue and so during early pregnancy, estrogen enhanced the uterine epithelium for the secretion of Lactoferrin and so increased epithelial and stromal cell proliferation. Nichols and McKee 1990 showed that Lactoferrin's role in the proliferation of epithelial cells was due to its ability for iron transportation inside the cells. Moreover, Hagiwara 1995 reported that the role of Lactoferrin in stimulating cell proliferation was due to stimulation of growth factor as one of its modulatory actions. Eosinophil count increased in the lactoferrin group as showed in Figure 6 in uterine tissue, particularly at 3 days after insemination when compared with the control group. These data get inconsistent with the results of added that eosinophil was decreased in uterine tissue with the advancement of Pregnancy. However, Robertson 2000 reported that eosinophil cells were present in rodent uterine tissue, particularly at early Pregnancy.

Their numbers increased after exposure to semen after mating within the uterine stroma, particularly at the area adjacent to the luminal and glandular epithelium. The migration of eosinophil and leukocyte to uterine tissue maybe had a role in implantation and attracted to granulocyte-macrophage colony-stimulating factor, interleukin 4 and interleukin 5 molecules. This could explain that Lactoferrin increased eosinophil particularly at 5hrs and 1 day after insemination in uterine tissues, and this may explain that eosinophil had a role in the implantation of the embryo and it may secrete chemical mediators or cytokines as Rantes, Eotaxin, MIP, and IL5 that aided in early embryo acceptance by immunity and may have a role in early implantation of the embryo.

\section{Conclusion}

Lactoferrin increases the number of leukocytes, especially lymphocytes, eosinophil, and basophil, and increases TNF and C-reactive protein in serum. In addition to that, increase the concentration of interleukin $1 \mathrm{~A}$ and interleukin 10, especially with the advancement of pregnancy at 3 and 7 days of gestation. So Lactoferrin has a positive effect on stimulating the general and mucosal immune system during pregnancy.

\section{Disclosures}

The authors have no declaration of interest associated with this publication.

\section{References}

1. Actor J, SA Hwang, M Kruzel (2009) Lactoferrin as a Natural Immune Modulator. Curr Pharm Des 15(17): 1956-1973.

2. Ahmed N, R Thorley, D Xia, D Samols, RO Webster (1996) Transgenic mice expressing rabbit $\mathrm{C}$-reactive protein exhibit diminished chemotactic factor-induced alveolitis. Am J Respir Crit Care Med 153(3): 1141-1147.

3. Bancroft JD, M Gamble (2002) Theory and Practice of Histological Techniques (Churchill Livingstone, London, UK) $\left(6^{\text {th }}\right.$ Edn.).,. In: Bancroft JD, M Gamble(Eds.)., Elsevier, Netherlands, pp. 744.

4. Batzer FR (1980) Hormonal evaluation of early pregnancy. Fertil Steril 34(1): 1-13.

5. Bergquist C, SJ Nillius, L Wide (1983) Human gonadotropin therapy. I. Serum estradiol and progesterone patterns during conceptual cycles. Fertil Steril 39(6): 761-765.

6. Bourdiec A, A Akoum (2014) L'implantation embryonnaire-Importance de la famille de l'interleukine 1. médecine/sciences. 30(6-7): 644-650.

7. Clark DA, G Chaouat, PC Arck, HW Mittruecker, GA Levy (1998) Cutting Edge: Cytokine-Dependent Abortion in CBA $\times$ DBA/2 Mice Is Mediated by the Procoagulant fgl2 Prothombinase. J Immunol 160 (2): 545-549.

8. Cooper MA, TA Fehniger, SC Turner, KS Chen, BA Ghaheri (2001) Human natural killer cells: A unique innate immunoregulatory role for the CD56bright subset. Blood 97(10): 3146-3151.

9. Cornish J, KE Callon, D Naot, KP Palmano, T Banovic, et al. (2004) Lactoferrin is a potent regulator of bone cell activity and increases bone formation in vivo. Endocrinology 145(9): 4366-4374.

10. Dealtry GB, MK O Farrell, N Fernandez (2000) The cytokine environment of the placenta. Int Arch Allergy Immunol 123(2):107-119.

11. Duarte DC, A Nicolau, JA Teixeira, LR Rodrigues (2011) The effect of bovine milk lactoferrin on human breast cancer cell lines. J Dairy Sci 94(1): 66-76. 
12. Faas MM, GA Schuiling, EA Linton, IL Sargent, CWG Redman (2000) Activation of peripheral leukocytes in rat pregnancy and experimental preeclampsia. Am J Obstet Gynecol 182(2): 351-357.

13. Felicio LS, JF Nelson, CE Finch (1984) Longitudinal studies of estrous cyclicity in aging C57BL/6J mice: II. Cessation of cyclicity and the duration of persistent vaginal cornification. Biol Reprod 31(3): 446-453.

14. Filant J, TE Spencer (2013) Endometrial glands are essential for blastocyst implantation and decidualization in the mouse uterus. Biol Reprod 88(4): 93.

15. Finn CA, AM Lawn (1967) Specialized junctions between decidual cells in the uterus of the pregnant mouse. J Ultrasructure Res 20(5): 321-327.

16. Fowden AL, AJ Forhead, PM Coan, GJ Burton (2008) The placenta and intrauterine programming. Journal of Neuroendocrinology 20(4): 43950.

17. Gahr M, CP Speer, B Damerau, G Sawatzki (1991) Influence of lactoferrin on the function of human polymorphonuclear leukocytes and monocytes. J Leukoc Biol 49(5): 427-33.

18. Goldman S, E Shalev (2007) Progesterone receptor profile in the decidua and fetal membrane. Front. Biosci 12: 634-648.

19. Greenwald GS (1967) Luteotropic complex of the hamster. Endocrinology 80(1): 118-30.

20. Guerra Infante FM, I Estrada Carlos, M Lopez Hurtado (1999) Phagocytic activity of polymorphonuclear leukocytes of pregnant women. Rev Latinoam Microbiol 41(2): 47-51.

21. (2013) Guidelines for veterinary personal Biosecurity. Australian Veterinary Association Infection control manual (2014): Animal health center, college of veterinary Medicine, Mississippi State University.

22. Guilbert LJ (1996) There is a bias against type 1 (inflammatory) cytokine expression and function in pregnancy. J Reprod Immunol 32(2): 105110.

23. Guillén C, IB McInnes, DM Vaughan, S Kommajosyula, PHC Van Berkel (2002) Enhanced Th1 Response to Staphylococcus aureus. J Immunol 168(8): 3950-3957.

24. Infection in Human Lactoferrin-Transgenic Mice. J Immunol, pp. 168.

25. Hagiwara T, I Shinoda, Y Fukuwatari, S Shimamura (1995) Effects of Lactoferrin and Its Peptides on Proliferation of Rat Intestinal Epithelial Cell Line, IEC-18, in the Presence of Epidermal Growth Factor. Biosci Biotechnol Biochem 59(10):1875-1881.

26. Haider S, M Knöfler (2009) Human Tumour Necrosis Factor: Physiological and Pathological Roles in Placenta and Endometrium. Placenta 30(2): 111-123

27. Hanna N, I Hanna, M Hleb, E Wagner, J Dougherty (2000) Gestationa Age-Dependent Expression of IL-10 and Its Receptor in Human Placenta Tissues and Isolated Cytotrophoblasts. J Immunol 164(11): 5721-5728.

28. Huet Hudson YM, GK Andrews, SK Dey (1989) Cell type-specific localization of c-myc protein in the mouse uterus: Modulation by steroid hormones and analysis of the peri implantation period. Endocrinology 125(3):1683-1690.

29. Hunt JS, L Miller, JS Platt (1998) Hormonal regulation of uterine macrophages. Developmental Immunology 6(1-2): 105-110.

30. Hunt JS, SA Robertson (1996) Uterine macrophages and environmental programming for pregnancy success. J Reprod Immunol 32(1): 1-25.

31. Juhász K, K Buzás, E Duda (2013) Importance of reverse signaling of the TNF superfamily in immune regulation. Expert Rev Clin Immunol 9(4): 335-348.
32. Kitzmiller JL, RE Rocklin (1980) Lack of suppression of lymphocyte MIF production by estradiol, progesterone and human chorionic gonadotropin. J Reprod Immunol 1(5-6): 297-306.

33. Kline JA, GW Williams, J Hernandez Nino (2005) D-dimer concentrations in normal pregnancy: new diagnostic thresholds are needed. Clin Chem 51(5): 825-829.

34. Koracevic D, G Koracevic, V Djordjevic, S Andrejevic, V Cosic (2001) Method for the measurement of antioxidant activity in human fluids. J Clin Pathol 54(5): 356-361.

35. Kowalik MK, D Slonina, R Rekawiecki, Kotwica (2013) Expression of progesterone receptor membrane component (PGRMC) 1 and 2, serpine mRNA binding protein 1 (SERBP1) and nuclear progesterone receptor (PGR) in the bovine endometrium during the estrous cycle and the first trimester of pregnancy. Reprod Biol 13(1): 15-23.

36. Lawen A, DJR Lane (2013) Mammalian iron homeostasis in health and disease: Uptake, storage, transport, and molecular mechanisms of action. Antioxidants Redox Signal 18(18): 2473-507.

37. Legrand D (2012) Lactoferrin, a key molecule in immune and inflammatory processes. Biochem Cell Biol 90(3): 252-268.

38. Levin ER (2015) Extranuclear steroid receptors are essential for steroid hormone actions. Annu Rev Med 66: 271-280.

39. Maneva A, B Taleva, L Maneva (2003) Lactoferrin-protector against oxidative stress and regulator of glycolysis in human erythrocytes. Zeitschrift fur Naturforsch. Sect CJ Biosci 58(3-4): 256-262.

40. Mulder AM, PA Connellan, CJ Oliver, CA Morris, LM Stevenson (2008) Bovine lactoferrin supplementation supports immune and antioxidant status in healthy human males. Nutr Res 28(9): 583-589.

41. Nakashima T, M Hayashi, H Takayanagi (2012) New insights into osteoclastogenic signaling mechanisms. Trends Endocrinol Metab 23(11): 582-590.

42. Newbold RR, CT Teng, WC Beckman, WN Jefferson, RB Hanson (1992) Fluctuations of lactoferrin protein and messenger ribonucleic 605 acid in the reproductive tract of the mouse during the estrous cycle. Biol Reprod 47(5): 903-915.

43. Nichols BL, KS McKee (1990) Lactoferrin as a dietary ingredient promoting the growth of the gastrointestinal tract.

44. Van Nieuwenhoven ALV, A Bouman, H Moes, MJ Heineman, LFMH de Leij (2002) Cytokine production in natural killer cells and 611 lymphocytes in pregnant women compared with women in the follicular phase of the ovarian 612 cycle. Fertil Steril 77(5): 1032-1037.

45. Nishiya K, DA Horwitz (1982) Contrasting effects of lactoferrin on human lymphocyte 614 and monocyte natural killer activity and antibodydependent cell-mediated cytotoxicity. J Immunol 129(6): 2519-2523.

46. Nwagha UI, FE Ejezie (2005) Serum ascorbic acid levels during pregnancy in Enugu, Nigeria. J coll Med 10(1): 43-45.

47. Ohta Y, T Sato, T Iguchi (1993) Immunocytochemical localization of progesterone receptor in the reproductive tract of adult female rats Biol Reprod 48(1): 205-213.

48. Parr MB, HN Tung, EL Parr (1986) The ultrastructure of the rat primary decidual zone. Am J Anat 35(4): 1045-1058.

49. Pihlanto Leppälä A, P Koskinen, K Phlola, T Tupasela, H Korhonen (2000) Angiotensin I-converting enzyme inhibitory properties of whey protein digests: Concentration 625 and characterization of active peptides. J Dairy Res 67(1): 53-64.

50. Yuan JS, A Reed, F Chen, CN Stewart (2006) Statistical analysis of realtime PCR data. BMC Bioinformatics. 7(1): 85. 
51. Rae MT, D Niven, A Ross, T Forster, R Lathe (2004) Steroid signalling in human ovarian surface epithelial cells: The response to interleukin-1 $\alpha$ determined by microarray analysis. J Endocrinol 183(1): 19-28.

52. Raghupathy R, M Makhseed F, Azizieh MM, K Al Azemi, NA Hassan (1999) Th1 and Th2 cytokine profiles in successful pregnancy and unexplained 635 recurrent abortions. Reproductive immunology. Springer 16(10): 2219-2226.

53. Robertson SA, VJ Mau, IG Young, KI Matthaei (2000) Uterine eosinophils and reproductive performance in interleukin 5-deficient mice. J Reprod Fertil 120(2): 423-4232.

54. Romem Y, R Artal (1984) C-reactive protein as a predictor for chorioamnionitis in cases 640 of premature rupture of the membranes. Am J Obstet Gynecol 150(5 Pt 1): 546-550.

55. Roth I, SJ Fisher (1999) IL-10 is an autocrine inhibitor of human placental cytotrophoblast MMP- 9 production and invasion. Dev Biol 205(1): 194-204.

56. Sallinen K, E Veräjänkorva, P Pöllänen (2000) Expression of antigens involved in the presentation of lipid antigens and induction of clonal anergy in the female reproductive 647 tract. J Reprod Immunol 46(2): 91-101.

57. Shin K, K Yamauchi, S Teraguchi, H Hayasawa, M Tomita (1998) Antibacterial activity of bovine lactoferrin and its peptides against 650 enterohaemorrhagic Escherichia coli 0157: H7. Lett Appl Microbiol 26(6): 407-411.

58. Takakura N, H Wakabayashi, H Ishibashi, K Yamauchi, S Teraguchi (2004) Effect of orally administered bovine lactoferrin on the immune response in the oral candidiasis murine model. J Med Microbiol 53(pt 6): 495-500.

59. Tang Y, W Xiang, L Terry, HA Kretzschmar, O Windl (2010) Transcriptional 656 analysis implicates endoplasmic reticulum stress in bovine spongiform encephalopathy. PLoS One 5(12): e14207.

60. Teng CM, JP Wang, TF Huang, MY Liau (1989) Effects of venom proteases on peptide chromogenic substrates and bovine prothrombin. Toxicon 27(2): 161-167.

61. Tewari N, S Kalkunte, DW Murray, S Sharma (2009) The water channe aquaporin 6611 is a novel molecular target of polychlorinated biphenyls for in utero anomalies. J Biol Chem 284(22): 15224-15232.

\section{ISSN: 2574-1241}

DOI: 10.26717/BJSTR.2021.37.006061

Nada Mohamed Ali Hashem. Biomed J Sci \& Tech Res

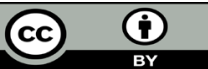

This work is licensed under Creative

Commons Attribution 4.0 License

Submission Link: https://biomedres.us/submit-manuscript.php
62. Thompson EA, S Ferraris, T Gress, V Ferraris (2005) Gender differences and 664 predictors of mortality in spontaneous coronary artery dissection: a review of reported cases. J Invasive Cardiol 17(1): 59-61.

63. Togawa J, H Nagase, K Tanaka, M Inamori, A Nakajima (2002) Oral administration of lactoferrin reduces colitis in rats 668 via modulation of the immune system and correction of cytokine imbalance. J Gastroenterol Hepatol 17(12): 1291-1298.

64. Urdal P, SM Borch, S Landaas, MB Krutnes, GO Gogstad (1992) Rapid immunometric measurement of C-reactive protein in whole blood. Clin Chem 38(4): 580-584

65. Valenti P, G Antonini (2005) Lactoferrin. Cell Mol Life Sci 62: 2576

66. Wakabayashi H, M Takase, M Tomita (2003) Lactoferricin derived from milk protein lactoferrin. Curr Pharm Des 9(16): 1277-1287.

67. Ward PP, OM Conneely (2004) Lactoferrin: role in iron homeostasis and host defense against microbial infection. Biometals 17(3): 203-208.

68. Wira CR, M Rodriguez Garcia, MV Patel (2015) The role of sex hormones in immune protection of the female reproductive tract. Nat Rev Immunol 15: $217-230$.

69. Wilk KM, Hwang SA, Actor JK (2007) Lactoferrin Modulation of Antigen Presenting-Cell Response to BCG Infection: Wpływ laktoferryny na odpowiedź komórek prezentujących antygen zakażonych BCG. Postepy higieny i medycyny doswiadczalnej (Online) 61: 277-282.

70. Yamauchi K, T Toida, S Nishimura, E Nagano, O Kusuoka (2000) 13-Week oral repeated administration 686 toxicity study of bovine lactoferrin in rats. Food Chem Toxicol 38(6): 503-512.

71. Zheng J, ML Johnson, DA Redmer, LP Reynolds (1996) Estrogen and progesterone receptors, cell proliferation, and c-fos expression in the ovine uterus during early pregnancy. Endocrinology 137(1): 340-348.

72. Zimecki M, J Mazurier, G Spik, JA Kapp (1995) Human lactoferrin induces phenotypic and functional changes in murine splenic B cells. Immunology 86(1): 122-127.

73. Potkul RK, AH Moawad, KL Ponto (1985) The association of subclinical infection 627 with preterm labor: The role of C-reactive protein. Am J Obstet Gynecol 153(6): 642-645.

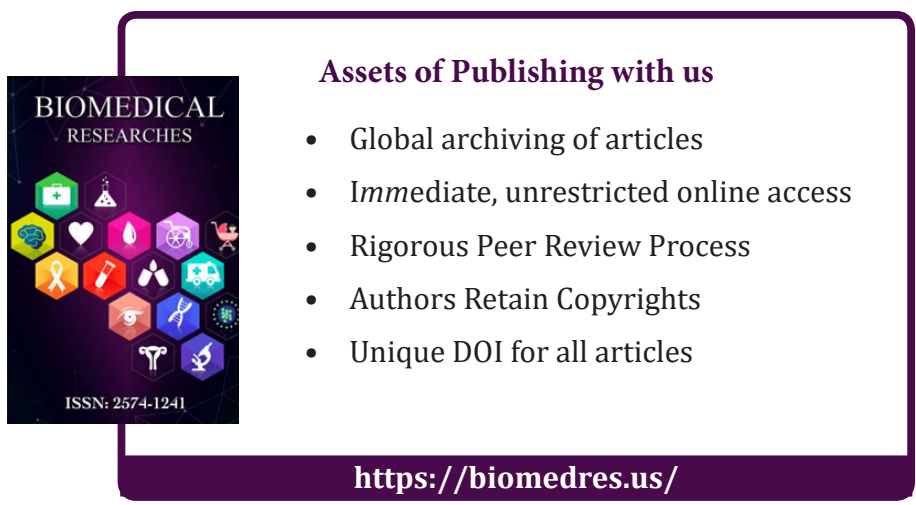

